\title{
Kemampuan Argumentasi Peserta Didik dalam Menyelesaikan Masalah Pembuktian Kongruensi Segitiga Ditinjau dari Perbedaan Gender
}

\author{
Nadia Ummi Sholihah ${ }^{1}$, Lisanul Uswah Sadieda ${ }^{1 *}$, Sutini ${ }^{1}$ \\ ${ }^{1}$ Program Studi Pendidikan Matematika, UIN Sunan Ampel Surabaya \\ ${ }^{*}$ Corresponding Author: lisanuluswah@uinsby.ac.id
}

\begin{tabular}{l} 
ARTICLE INFO \\
\hline Article history: \\
Received 7 Feb 2021 \\
Revised 19 May 2021 \\
Accepted 25 May 2021 \\
\\
Keywords: \\
Argumentations, \\
Proof, Toulmin, \\
Triangular \\
Congruence, Gender
\end{tabular}

How to cite:

Sholihah, N. U., Sadieda, L. U, \& Sutini, S. (2021). Kemampuan Argumentasi Peserta Didik Dalam Menyelesaikan Masalah Pembuktian Kongruensi Segitiga Ditinjau Dari Perbedaan Gender. JRPM (Jurnal

Review Pembelajaran Matematika), 6(1), 24-38. \begin{abstract}
This research aims to describe the argumentative abilities of male and female students to solve the triangular congruence proof problems. This research is a qualitative descriptive research. The subjects used in this research were 4 students of class X-MIPA1 at MAN Sumenep consisting of 2 male students and 2 female students. Sampling was done by using purposive sampling type quota sampling. Data collection techniques used written tests and interviews, then analyzed based on the indicators of Toulmin's argumentative ability consisting of claims, evidence, warrant, backing, qualifier, and rebuttal. The results showed that there were differences in the argumentation skills possessed by male and female students, as shown in the following data: (1) Male students were at level 1 in conveying their arguments with the fulfilled indicator being a claim. Male students tend to be more careless in solving problems, but they rely more on their verbal skills in answering. (2) Female students are able to reach level 3 in conveying their arguments with the indicators that are fulfilled are claim, evidence, and warrant. Female students tend to be thorough in working on questions and rely more on their symbolic abilities in answering.
\end{abstract}

(C) 2021 The Author(s) Published by JRPM (Jurnal Review Pembelajaran Matematika) This is an open access article under CC BY-SA license (https:// creativecommons.org/licenses/by-sa/4.0/)

\section{PENDAHULUAN}

Argumen merupakan inti dari penulisan karya ilmiah dalam dunia pendidikan (Handayani, 2015). Pendapat yang disampaikan oleh seorang penulis terhadap suatu gejala, konsep atau teori harus dapat meyakinkan pembacanya. Dengan adanya argumen tersebut, seseorang akan terdorong untuk berusaha mencari tahu pandangan mana yang lebih baik dari yang lain agar dapat meyakinkan dirinya sendiri. Hal ini sejalan dengan karakteristik 
suatu argumen yang bersifat persuasif yang artinya mempengaruhi apakah pernyataan tersebut dapat diterima atau ditolak (Ruggiero, 2009). Dengan demikian, kemampuan seseorang dalam berargumen sangatlah penting terutama dalam hal meyakinkan diri sendiri dan orang lain.

Kemampuan berargumentasi seseorang baik lisan dan tulisan akan didukung oleh pemahaman konsep dan penalaran yang dimilikinya. Pemahaman seseorang sangatlah penting terhadap kualitas argumentasi yang diberikan. Dalam matematika, kemampuan berargumentasi dapat dilihat ketika mengkonstruk suatu bukti dari pernyataan yang masih perlu dicari nilai kebenarannya. Menurut Syamsuri \& Santosa (2017) pemahaman matematis peserta didik sangat diperlukan untuk mengkonstruk bukti matematis yang baik. Bukti matematis yang baik adalah yang memuat argumen yang logis dan bersifat deduktif. Argumen dikatakan logis jika setiap pernyataannya didukung oleh data, fakta dan konsep. Sedangkan argumen bersifat deduktif artinya argumen yang diberikan harus didasarkan oleh definisi, aksioma, postulat dan teorema terdahulu yang telah dinyatakan kebenarannya dalam sistem logika formal. Hal ini menunjukkan bahwa bukti digunakan untuk memverifikasi kebenaran pernyataan matematika yang diberikan (Sadieda, 2019). Bukti harus dapat membantu orang lain untuk memahami kebenaran suatu pernyataan.

Kualitas argumentasi peserta didik dalam menyusun bukti matematis dapat dianalisis menggunakan model argumentasi Toulmin. Model yang dikenal dengan Toulmin's Argumen Pattern (TAP) ini menjelaskan kerangka dalam memberikan suatu argumen. Komponen argumentasi Toulmin terdiri dari claim, evidence, warrant, backing, qualifier dan rebuttal (Meylani, 2018). Claim berupa pernyataan atau tanggapan awal pembicara terhadap permasalahan yang diberikan. Dalam konteks penelitian ini, claim merupakan dugaan, penjelasan, atau simpulan awal peserta didik terhadap masalah yang akan diselesaikan. Evidence adalah bukti atau data yang digunakan untuk mendukung claim. Warrant adalah alasan yang diberikan peserta didik untuk menghubungkan claim dan data/informasi yang muncul pada soal. Backing/pendukung merupakan asumsi-asumsi dasar yang sering tidak dimunculkan secara eksplisit karena dianggap telah disepakati bersama untuk membenarkan alasan/warrant. Qualifier adalah kondisi yang diperlukan agar claim itu bernilai benar, dan mewakili keterbatasannya. Rebuttal adalah pernyataan-pernyataan yang mengantisipasi kebenaran suatu simpulan/sanggahan.

Penelitian ini menggunakan model argumentasi Toulmin untuk menganalisis kemampuan argumentasi peserta didik dalam menyelesaikan masalah pembuktian geometri 
khususnya pada konsep kongruensi segitiga ditinjau dari perbedaan gender. Kongruensi segitiga merupakan salah satu materi dalam geometri di sekolah tingkat menengah yang sering diaplikasikan untuk memecahkan berbagai permasalahan dalam geometri. Materi ini juga memuat banyak teorema dan pernyataan yang membutuhkan pembuktian. Kemampuan argumentasi peserta didik dalam membuktikan kekongruenan segitiga sangat menarik untuk diteliti karena pada materi inilah pertama kalinya peserta didik SMP diperkenalkan pada proses pembuktian matematis menggunakan pola pikir deduktif. Apalagi bagi peserta didik, geometri merupakan salah satu materi yang sulit untuk dipelajari. Hal ini tampak dari hasil penelitian Sunardi \& Yudianto (2015) yang menunjukkan bahwa $74,4 \%$ dari 82 peserta didik yang mengikuti ulangan harian geometri mendapat nilai kurang dari 60. Selain itu konsep kongruensi dan kesebangunan juga merupakan salah satu konsep dalam geometri yang sulit untuk dipahami $\mathrm{Hal}$ ini ditunjukkan oleh penelitian Mutohar (2016) yang menjelaskan banyaknya kesalahan dalam menyelesaikan masalah kongruensi dan kesebangunan karena peserta didik masih kurang memahami konsepnya. Bahkan dalam penelitian Retnosari (2017) menunjukkan bahwa mahasiswa calon guru tidak memiliki kemampuan dalam menjelaskan definisi konsep kekongruenan dan kesebangunan.

Beberapa penelitian terdahulu yang mengkaji tentang kemampuan argumentasi peserta didik menunjukkan bahwa peserta didik tingkat menengah kesulitan dalam menyusun argumen ilmiah. Pritasari dkk (2016) menyatakan bahwa peserta didik yang mampu memberikan claim secara tepat sebesar 61,62\% namun yang mampu menyusun bukti (evidence) hanya 15,66\%. Sejalan dengan itu, Faruq (2014) menyatakan bahwa 62,5\% peserta didikdi sekolah tingkat menengah kesulitan dalam mengkonstruk bukti terutama pada materi geometri. Sandoval \& Millwood (2005) menyatakan jika kesulitan dalam membuat argumen ilmiah juga dialami oleh peserta didik SMA di negara maju ketika proses diskusi di dalam kelas. Faktor internal yang mempengaruhi kemampuan argumentasi peserta didik salah satunya adalah tingkat aktualisasi peserta didik. Semakin rendah tingkat aktualisasi seseorang akan berbanding lurus dengan kemampuan argumentasinya (Nisa', 2017). Kemampuan seseorang untuk mengaktualisasikan dirinya sangat terkait dengan gender (Umroh, 2018; Budiati, 2010). Gender tidak lagi hanya berkaitan dengan masalah biologis saja tetapi kemudian berkembang menjadi perbedaan kemampuan antara laki-laki dan perempuan. Persepsi perempuan yang masih mengikuti nilai-nilai lama seringkali membatasi mereka untuk mengembangkan potensi yang ada dalam diri mereka dibanding 
laik-laki, begitu pula dalam dunia pendidikan.

Pasiak (2002) menyatakan bahwa struktur otak dan hormonal mempengaruhi cara berpikir peserta didik laki-laki dan perempuan. Perbedaan tersebut mengakibatkan terjadinya perbedaan dalam kemampuan verbal dan spasial, tingkah laku, bahasa, emosi, dan lain-lain. Hal ini didukung oleh beberapa penelitian yang menunjukkan bahwa adanya pengaruh gender terhadap kemampuan berpikir, penalaran, komunikasi matematis, koneksi matematis, dan pemecahan masalah (Aini dan Hasanah, 2019; Nafi'an, 2011; Salmina \& Nisa, 2018; Susilowati, 2016). Sejalan dengan hal tersebut, hasil survei PISA juga menunjukkan kemampuan bermatematika perempuan lebih tinggi dibandingkan laki-laki. Hal ini ditunjukkan dengan rata-rata kemampuan bermatematika peserta didik laki-laki sebesar 374 poin dan peserta didik perempuan sebesar 474 poin (OECD, 2019).

Berdasarkan permasalahan yang telah dikemukakan dan kajian teori yang telah diuraikan di atas, diduga bahwa kemampuan argumentasi peserta didik dalam mengkonstruk suatu bukti salah satunya dipengaruhi oleh faktor gender. Dengan demikian, berbeda dengan penelitian sebelumnya, penelitian ini bertujuan untuk mendeskripsikan level kemampuan argumentasi peserta didik dalam memecahkan masalah pembuktian kongruensi segitiga ditinjau dari perbedaan gender. Walaupun banyak studi yang menunjukkan kesulitan peserta didik dalam menyusun argumen, namun informasi mengenai level kemampuan argumentasi peserta didik ini akan membantu guru dalam mengidentifikasi permasalahan, pemberian metode pembelajaran yang sesuai serta mengawasi perkembangan kemampuan argumentasi setiap peserta didik mengingat pentingnya penguasaan materi kongruensi segitiga bagi peserta didik. Sesuai dengan pendapat Walidah, Kusaeri \& Yudi (2019) dalam penelitiannya yang menunjukkan kemampuan berargumentasi peserta didik di dalam kelas bergantung pada dukungan yang diberikan guru. Oleh karena itu, informasi yang diperoleh dari penelitian ini akan memberikan konstribusi bagi peningkatan kualitas pembelajaran matematika khususnya materi geometri di sekolah.

\section{METODE PENELITIAN}

Penelitian yang dilaksanakan di salah satu Madrasah Aliyah Negeri pada tahun pelajaran 2019/2020 ini termasuk dalam jenis penelitian deskriptif yang menggunakan pendekatan kualitatif. Subjek penelitian yang diambil menggunakan teknik purposive sampling tipe quota sampling ini adalah2 peserta didik laki-laki (SL) dan 2 peserta didik perempuan 
(SP) dengan syarat telah mempelajari materi kongruensi bangun dan memiliki kemampuan matematis yang relatif sama.

Teknik pengumpul data menggunakan 2 metode yaitu teknik tes dan wawancara. Teknik tes digunakan untuk mendapatkan data mengenai kemampuan argumentasi peserta didik dalam menyelesaikan masalah pembuktian kongruensi segitiga. Sedangkan teknik wawancara digunakan untuk memverifikasi jawaban serta memperoleh informasi-informasi yang sulit didapatkan pada saat mengerjakan soal tes. Wawancara dilakukan setelah subjek penelitian mengerjakan tes.

Instrumen yang digunakan dalam penelitian ini merupakan lembar tes kemampuan argumentasi yang telah divalidasi oleh dosen pendidikan matematika UIN Sunan Ampel Surabaya. Lembar tes kemampuan argumentasi ini terdiri dari 1 butir soal mengenai pembuktian kongruensi segitiga. Soal yang digunakan untuk menggali kemampuan argumentasi peserta didik dalam menyelesaikan masalah pembuktian adalah sebagai berikut:

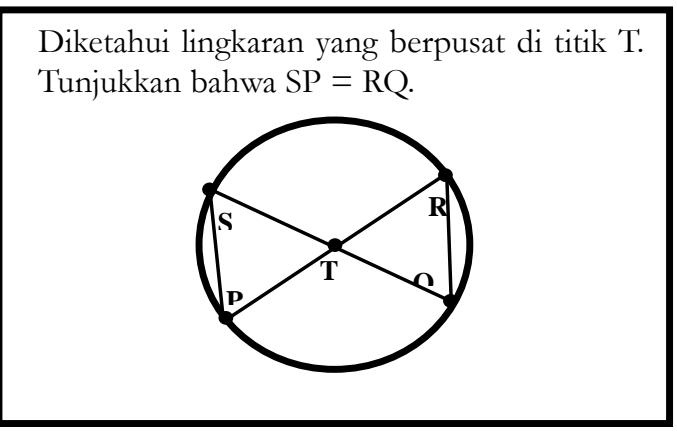

Gambar 1. Soal Tes Kemampuan

Data yang telah didapat, dikumpulkan untuk dilakukan triangulasi data dan dianalisis menggunakan analisis data Model Miles dan Huberman. Model ini terdiri dari beberapa aktivitas yang dilakukan, yaitu: pengumpul data, penyajian data, dan penarikan kesimpulan. Adapun indikator yang digunakan untuk penarikan simpulan tentang kemampuan argumentasi peserta didik dapat dilihat pada tabel 1 yang diadaptasi dari (Herlanti, 2014).

Tabel 1. Level Kemampuan Argumentasi

\begin{tabular}{|c|c|c|}
\hline Level & Komponen & Kriteria \\
\hline 1 & Claim & Hanya memberikan klaim yang benar \\
\hline 2 & Claim, Evidence, & $\begin{array}{l}\text { Mampu menyatakan klaim dan menyajikan data yang sesuai } \\
\text { dan benar }\end{array}$ \\
\hline 3 & Claim, Evidence dan Warrant & $\begin{array}{l}\text { Mampu menyatakan klaim, menyajikan data dan menjelaskan } \\
\text { alasan yang digunakan dengan benar }\end{array}$ \\
\hline 4 & $\begin{array}{l}\text { Claim, Evidence, Warrant, dan } \\
\text { Backing }\end{array}$ & $\begin{array}{l}\text { Mampu menyatakan klaim, menyajikan data dan menjelaskan } \\
\text { alasan dan pendukung yang digunakan dengan benar }\end{array}$ \\
\hline 5 & $\begin{array}{l}\text { Claim, Evidence, Warrant, } \\
\text { Backing, Qualifier, dan } \\
\text { Rebuttal }\end{array}$ & $\begin{array}{l}\text { Mampu menyatakan klaim, menyajikan data dan menjelaskan } \\
\text { alasan dan pendukung serta menunjukkan kualitas dari } \\
\text { simpulan yang digunakan dengan benar }\end{array}$ \\
\hline
\end{tabular}




\section{HASIL DAN PEMBAHASAN}

Hasil dan analisis data tes dan wawancara kemampuan argumentasi peserta didik dalam menyelesaikan masalah pembuktian kongruensi segitiga disajikan secara berturutturut mulai dari subjek laki-laki $\mathrm{SL}_{1}$ dan $\mathrm{SL}_{2}$ kemudian dilanjutkan subjek perempuan $\mathrm{SP}_{1}$ dan $\mathrm{SP}_{2}$.

Subjek $\mathrm{SL}_{1}$ mampu memberikan klaim yang benar dari permasalahan yang diberikan. Walaupun tidak menuliskan dalam lembar jawaban, namun hal ini tampak pada kutipan wawancara berikut:

$$
\begin{array}{ll}
\mathrm{P} & : \text { Apakah panjang } \mathrm{SP}=\mathrm{RQ} ? \\
\mathrm{SL}_{1} & : \text { Iya kak, benar kalau panjang } \mathrm{SP}=\mathrm{RQ}
\end{array}
$$

Namun $\mathrm{SL}_{1}$ tidak dapat memberikan bukti (evidence) dan alasan (warrant) yang mendukung klaimnya tersebut. Hal ini tampak dari Gambar 2 berikut:

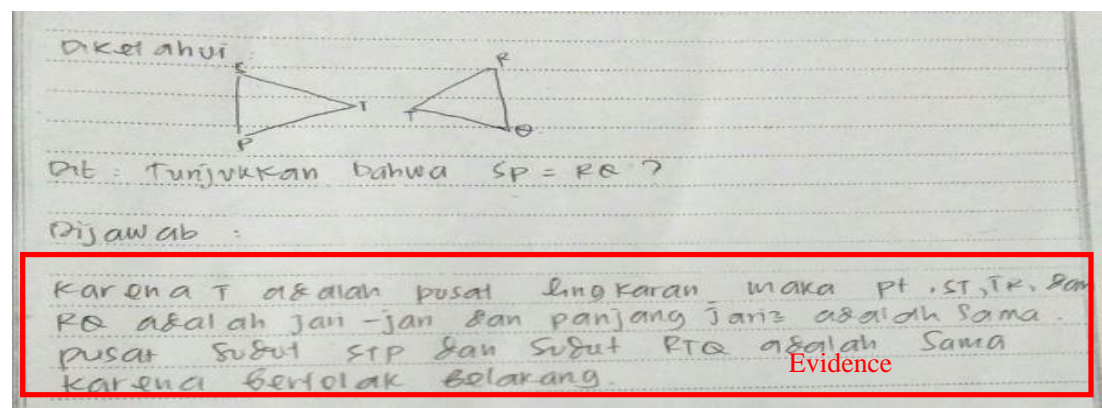

Gambar 2. Jawaban $\mathrm{SL}_{1}$

Gambar 2 menunjukkan bahwa $\mathrm{SL}_{1}$ memberikan bukti dengan menyusun semua informasi yang dapat diperoleh dari unsur lingkaran yang terdapat pada soal, yaitu jari-jari PT, ST, TR dan TQ yang panjangnya sama. SL $\mathrm{SL}_{1}$ juga menambahkan informasi bahwa besarnya sudut STP dan sudut RTQ adalah sama karena keduanya bertolak belakang. Hal ini menunjukkan bahwa $\mathrm{SL}_{1}$ memiliki pengetahuan yang cukup tentang konsep lingkaran dan hubungan antar sudut sehingga dia mampu menemukan semua informasi dalam soal.

Walaupun $\mathrm{SL}_{1}$ sudah menemukan semua informasi yang ada pada gambar, namun $\mathrm{SL}_{1}$ tidak dapat menghubungkan informasi yang didapat untuk membuktikan $\mathrm{SP}=\mathrm{RQ}$ sehingga bukti (evidence) yang diberikan tidak lengkap. Subjek $\mathrm{SL}_{1}$ tidak dapat memberikan evidence dan warrant yang tepat karena $\mathrm{SL}_{1}$ tidak memahami materi kongruensi dengan baik. Hal ini tampak sekali ketika wawancara dengan subjek, seperti pada kutipan wawancara berikut:

P : Soal ini kamu kerjakan menggunakan konsep apa?

$\mathrm{SL}_{1}$ : Pakai konsep kesebangunan kak, karena panjang sisinya sama

$\mathrm{P} \quad$ : Kalau kongruen menurutmu bagaimana?

$\mathrm{SL}_{1} \quad$ : Sama kak, hanya ukurannya berbeda 
Subjek $\mathrm{SL}_{1}$ menyatakan jika soal yang dia kerjakan berhubungan dengan konsep kesebangunan tetapi maksud dan makna yang dia berikan merupakan kekongruenan. Subjek $\mathrm{SL}_{1}$ terbalik dalam memahami konsep kesebangunan dan kekongruenan. Hal ini menunjukkan adanya kekeliruan terhadap konsep yang dia pelajari. Oleh karena itu, $\mathrm{SL}_{1}$ tidak dapat mengkonstruk argumen yang baik.

Tidak jauh berbeda dengan $\mathrm{SL}_{1}$, pada Gambar 3, $\mathrm{SL}_{2}$ juga memberikan klaimyang sama yang menyatakan jika garis $\mathrm{SP}=\mathrm{RQ}$. $\mathrm{SL}_{2}$ juga memberikan bukti jika panjang $\mathrm{PT}=\mathrm{ST}=\mathrm{RT}=\mathrm{QT}$.

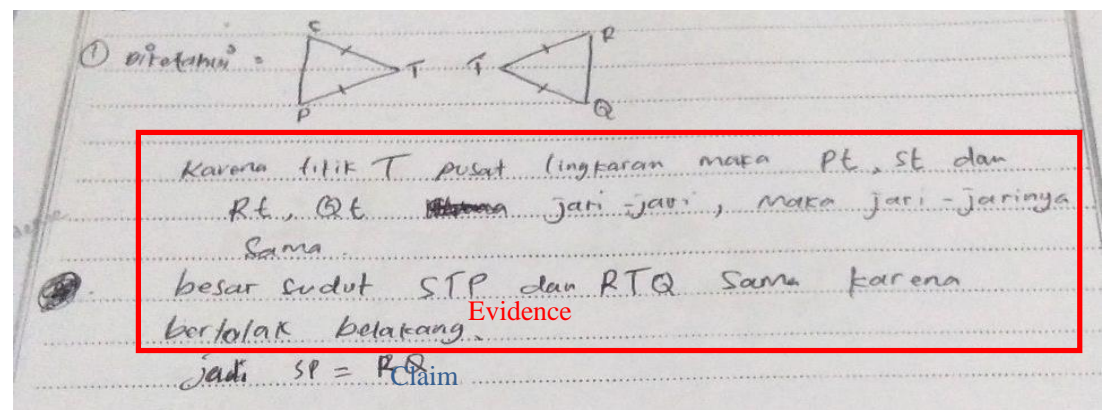

Gambar 3. Jawaban $\mathrm{SL}_{2}$

$\mathrm{SL}_{2}$ juga memulai pembuktian dengan menuliskan semua informasi yang dapat diperoleh dari soal. $\mathrm{SL}_{2}$ mengetahui jika sisi-sisi pada gambar yang dia buat merupakan sisi yang sama panjang dikarenakan titik $\mathrm{T}$ yang merupakan pusat lingkaran. $\mathrm{SL}_{2}$ mengetahui jika besar sudut yang saling bertolak belakang adalah sama. Berdasarkan hal tersebut, $\mathrm{SL}_{2}$ sebenarnya juga telah mengetahui dengan baik unsur-unsur dalam lingkaran dan hubungan antar sudut. Namun sama halnya dengan $\mathrm{SL}_{1}, \mathrm{SL}_{2}$ hanya menuliskan informasi yang telah dia peroleh tanpa mengkaitkan informasi tersebut untuk membuktikan $\mathrm{SP}=\mathrm{RQ}$. Walaupun sebenarnya $\mathrm{SL}_{2}$ mengetahui jika dua gambar yang dia buat merupakan bangun yang kongruen. Hal ini tampak pada kutipan wawancara berikut:

$\mathrm{P} \quad$ : Menurutmu bagaimana hubungan dua segitiga ini?

$\mathrm{SL}_{2} \quad$ : Keduanya kongruen kak, karena panjang sisi, jari-jari dan besar sudutnya semua sama.

$\mathrm{SL}_{2}$ menyatakan bahwa segitiga tersebut kongruen, namun dia tidak dapat menuliskan argumen logis dari pernyataannya. $\mathrm{SL}_{2}$ tidak dapat menjelaskan postulat maupun teorema yang dapat digunakan sebagai dasar pengambilan simpulannya. Hal ini tampak dalam kutipan wawancara berikut:

P : Baik, kamu sudah menyatakan bahwa dua segitiga tersebut kongruen, lalu apakah kamu langsung menyimpulkan bahwa $\mathrm{SP}=\mathrm{RQ}$ ?

$\mathrm{SL}_{2} \quad$ : Iya kak heheheh kan ukuran panjangnya sama 
Hal ini menunjukkan bahwa $\mathrm{SL}_{2}$ juga tidak dapat memberikan evidence dan warrant dengan baik sehingga argumen yang dihasilkan juga lemah.

Berdasarkan analisis di atas kedua subjek laki-lakimampu memberikan klaim dengan benar. Hanya saja kedua subjek laki-laki tidak dapat memberikan bukti dan alasan yang cukup untuk mendukung klaim yang diberikan. Keduanya hanya menuliskan informasi yang ada, tanpa menghubungkan informasi tersebut dengan postulat atau teorema kongruensi segitiga sehingga argumen yang diberikan lemah dan tidak logis. Subjek laki-lakijuga tidak memiliki pemahaman yang benar tentang konsep kongruensi segitiga dan sering tertukar dengan konsep kesebangunan. Hal ini berpengaruh terhadap ketidakmampuan kedua subjek laki-laki dalam menyusun bukti (evidence) dan alas an (warrant) yang tepat untuk membuktikan pernyataan yang diberikan. Oleh karena itu kemampuan argumentasi subjek laki-laki dalam menyelesaikan masalah pembuktian kongruensi segitiga berada pada level 1 karena hanya mampu memberikan klaim yang benar.

Selanjutnya adalah hasil tes dan analisis data untuk subjek perempuan. Subjek $\mathrm{SP}_{1}$ mampu memberikan klaim yang tepat. Hal ini dapat dilihat pada Gambar 4 berikut ini:

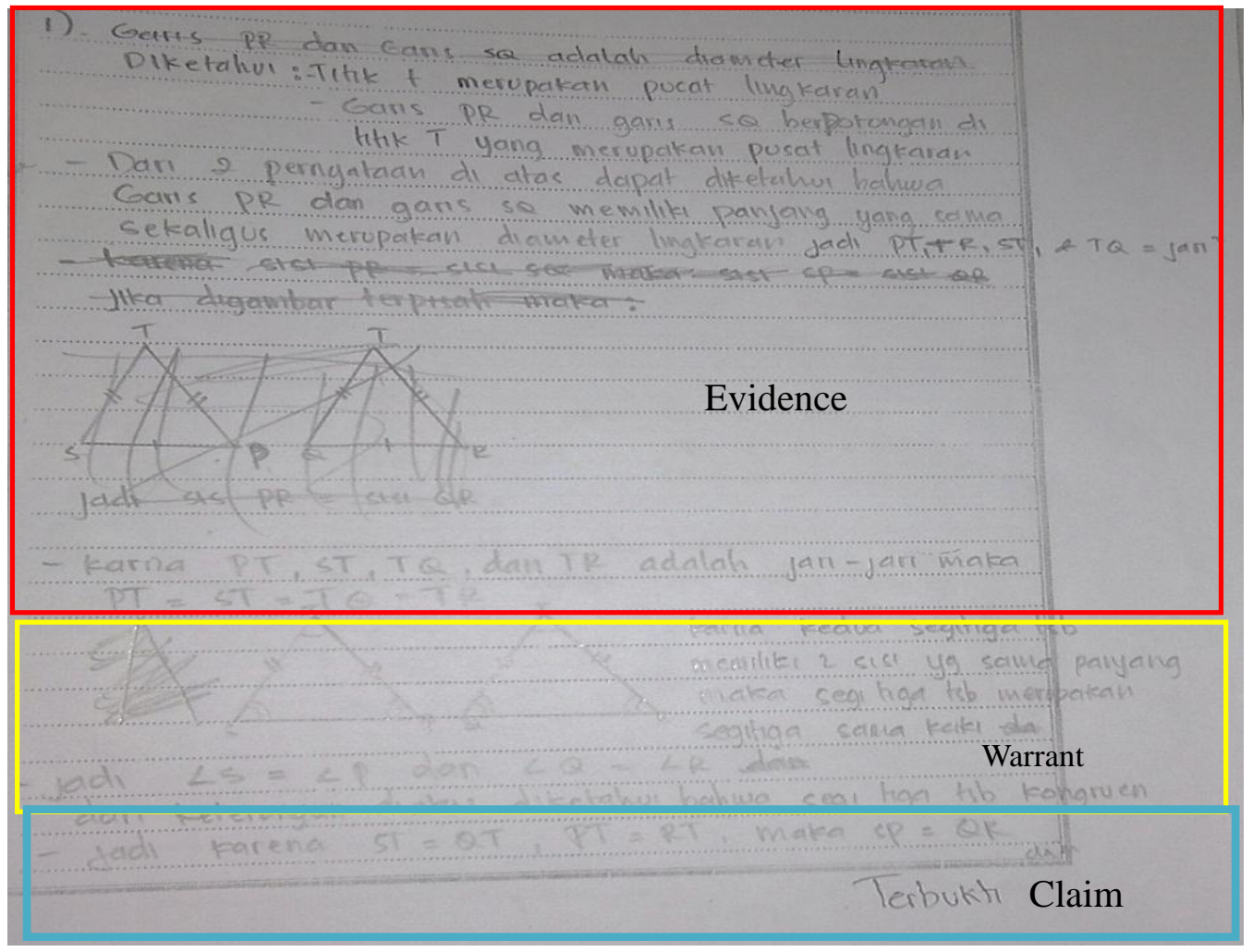

Gambar 4. Jawaban SP1 
$\mathrm{SP}_{1}$ juga mampu memberikan pendukung yang mampu membenarkan klaimyang ia buat. $\mathrm{SP}_{1}$ menuliskan karena garis $\mathrm{PR}$ dan $\mathrm{SQ}$ berpotongan pada titik pusat lingkaran maka garis PR dan SQ merupakan diameter lingkaran yang berpusat di $\mathrm{T}$ dan memiliki panjang yang sama. Hal ini berakibat $\mathrm{PT}=\mathrm{ST}=\mathrm{TR}=\mathrm{TQ}$ karena keempat garis tersebut merupakan jari-jari lingkaran yang tentunya memiliki panjang yang sama. $\mathrm{SP}_{1}$ mampu memberikan penjelasan yang menghubungkan antara klaim yang ia buat dengan bukti yang ia berikan. $\mathrm{SP}_{1}$ kemudian menggunakan konsep segitiga sama kaki untuk memberikan bukti untuk mendukung klaim yang diberikan, seperti tampak pada kutipan wawancara berikut:

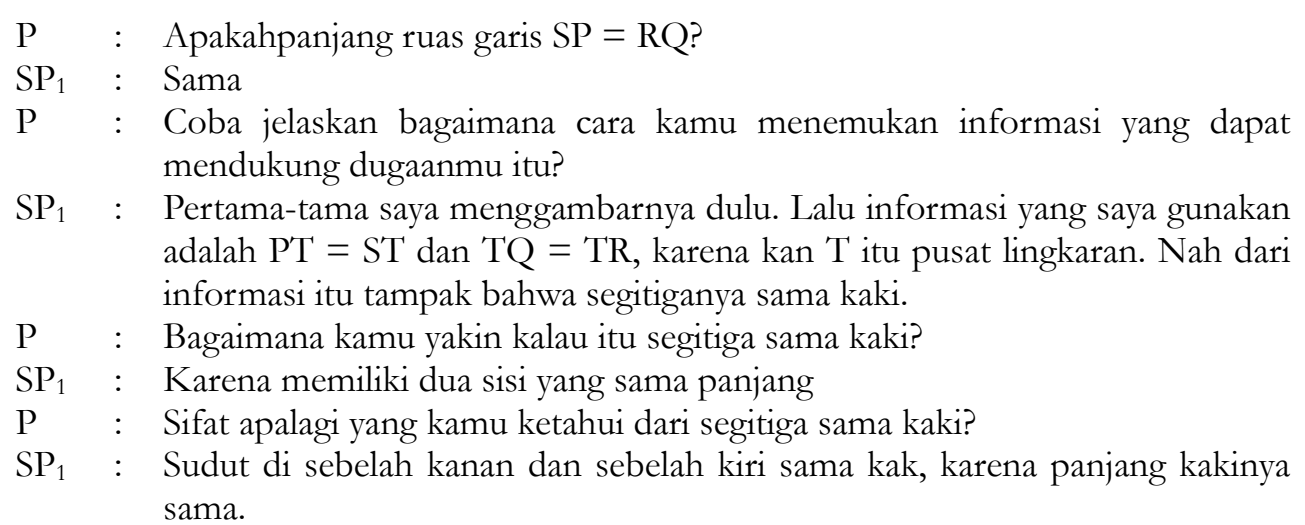

$\mathrm{SP}_{1}$ juga memberikan jawaban jika kedua segitiga sama kaki tersebut merupakan dua bangun yang kongruen. Hal ini tampak pada wawancara berikut:

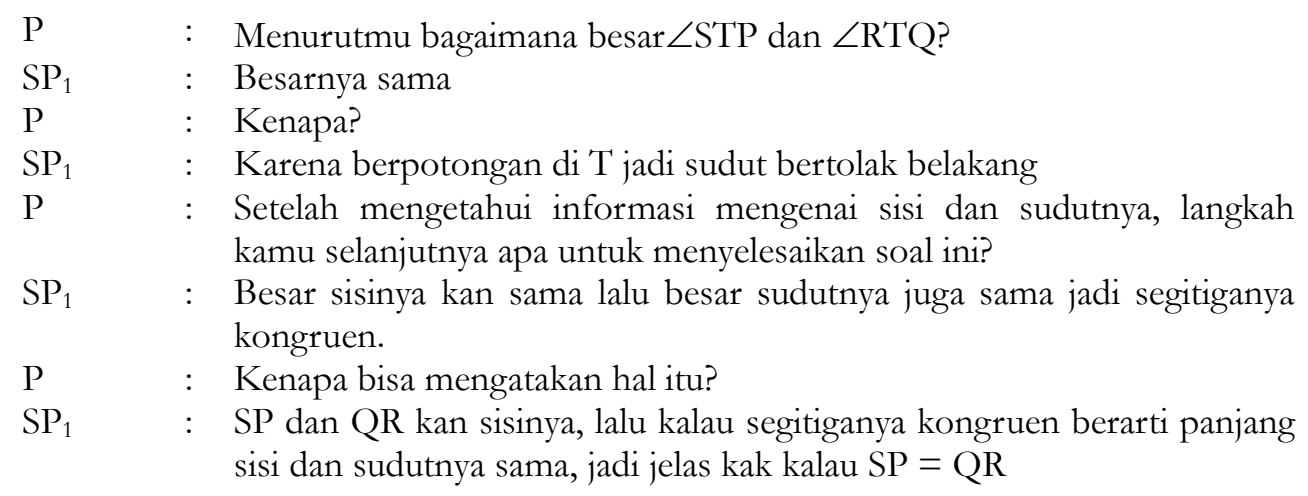

Namun, dari kutipan wawancara di atas tampak bahwa $\mathrm{SP}_{1}$ hanya menyebutkan sisi dan sudutnya sama tanpa menjelaskan dengan rinci sisi dan sudut mana yang sama serta teorema atau postulat apa yang digunakan. $\mathrm{SP}_{1}$ tidak dapat memberikan penjelasan yang lebih terkait kongruensi, sehingga $\mathrm{SP}_{1}$ tidak dapat memberikan alasan (warrant) yang tepat tentang kekongruenan $\triangle \mathrm{STP}$ dan $\triangle \mathrm{RTQ}$ berdasarkan teorema atau postulat kongruensi segitiga. $\mathrm{SP}_{1}$ hanya menggunakan konsep-konsep dasar mengenai kongruensi yang telah ia pelajari. Namun tampak tidak yakin ketika ditanya masih mengingat teorema atau postulat kongruensi, seperti tampak pada kutipan wawancara berikut: 


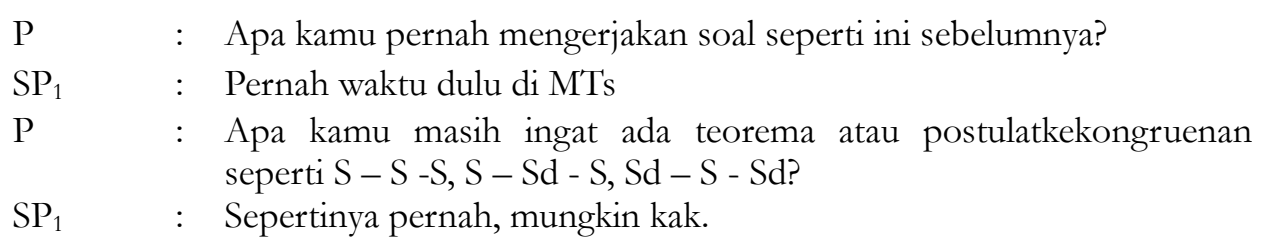

Di sisi lain, $\mathrm{SP}_{2}$ juga mampu memberikan klaim serta evidence yang tepat terhadap permasalahan yang diberikan, seperti tampak pada Gambar 5 berikut:

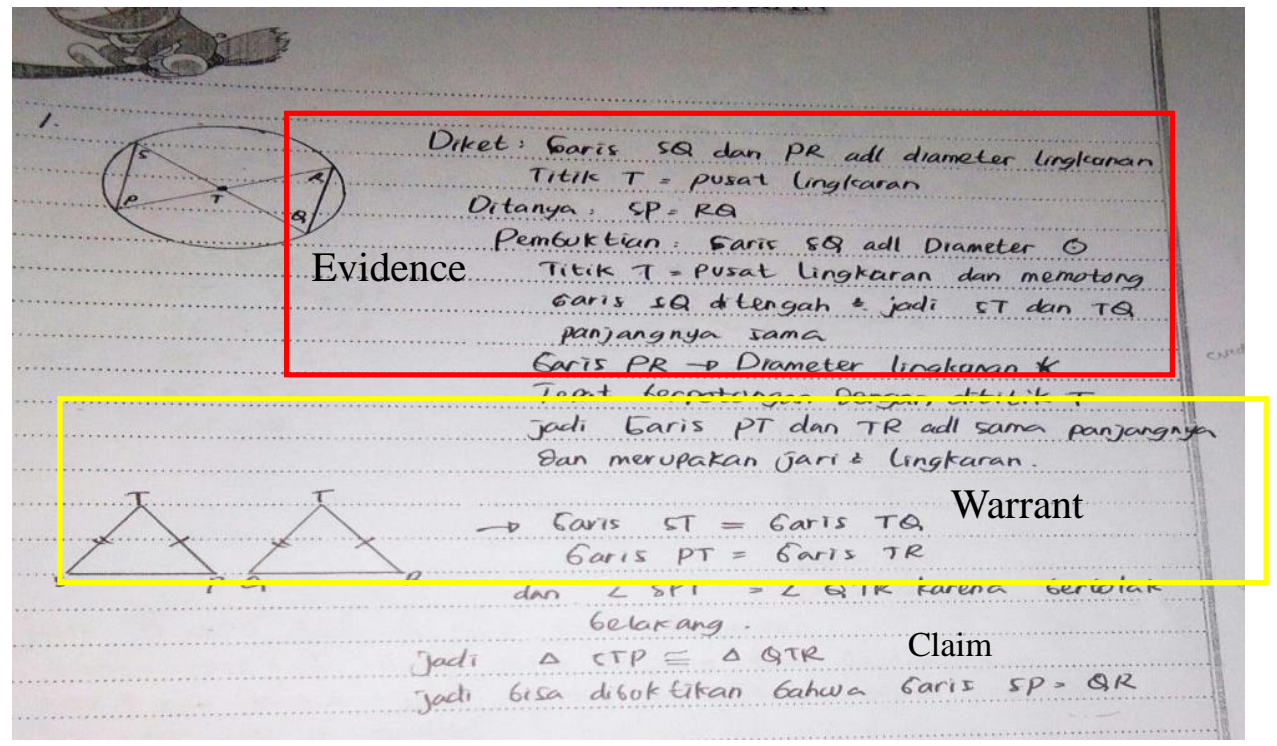

Gambar 5. Jawaban $\mathrm{SP}_{2}$

Pada Gambar 5, tampak bahwa $\mathrm{SP}_{2}$ mampu memberikan klaim yang tepat dengan memberikan bukti yang mendukung. $\mathrm{SP}_{2}$ memulai pembuktian dengan menuliskan apa yang diketahui dan apa yang ditanya dengan tepat. Dia menyadari bahwa garis PR dan SQ merupakan diameter lingkaran yang berpusat di T yang mengakibatkan PT dan TR menjadi jari-jari lingkaran yang memiliki panjang sama. Kemudian dia menuliskan informasi yang diperoleh secara runtut. Berdasarkan informasi tersebut, $\mathrm{SP}_{2}$ juga mengetahui bahwa terdapat dua buah segitiga yang sama kaki. Meskipun tidak ditunjukkan pada lembar pengerjaannya, tetapi hal tersebut tampak pada kutipan wawancara berikut:

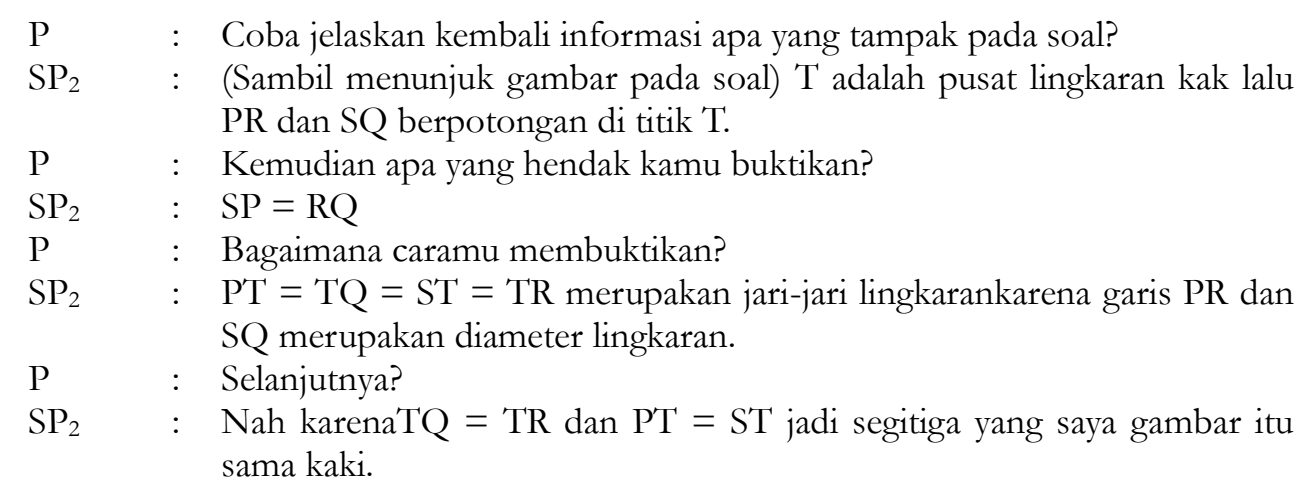


$\mathrm{P} \quad$ : Apakah kamu yakin?

$\mathrm{SP}_{2} \quad$ : Iya, karena dua sisinya sama, makanya disebut segitiga sama kaki.

P : Menurutmu apakah segitiga sama kaki memiliki sifat lain selain dua sisi yang sama panjang?

$\mathrm{SP}_{2} \quad$ : Kalau kakinya sama panjang maka sudut yang dibawah pasti juga sama. Dari gambarnya kelihatan kak, lalu karena sama-sama berpotongan di T maka $\angle \mathrm{T}$ sama dengan $\angle \mathrm{T}$.

Berbeda dengan $\mathrm{SP}_{1}, \mathrm{SP}_{2}$ menjelaskan dengan rinci sisi dan sudut mana yang digunakan untuk menentukan $\triangle \mathrm{STP}$ dan $\triangle \mathrm{RTQ}$. Berdasarkan gambar 5 tampak bahwa $\mathrm{SP}_{2}$ menuliskan $\mathrm{ST}=\mathrm{TQ}, \mathrm{PT}=\mathrm{PR}$ dan $\angle \mathrm{STP}=\angle \mathrm{QTR}$ yang berarti subjek $\mathrm{SP}_{2}$ menggunakan postulat S-Sd-S untuk menunjukkan $\Delta \mathrm{STP}$ dan $\Delta \mathrm{RTQ}$. Kemudian subjek $\mathrm{SP}_{2}$ juga dapat menjelaskan bahwa jika dua segitiga kongruen maka semua sisinya memiliki panjang yang sama dengan kata lain $\mathrm{SP}=\mathrm{QR}$, seperti tampak pada kutipan wawancara berikut:

$\mathrm{P} \quad$ : Jelaskan kembali bagaimana simpulanmu?

$\mathrm{SP}_{2} \quad$ : Segitiganya STP dan RTQ kongruen kak

$\mathrm{P} \quad$ : Selanjutnya?

$\mathrm{SP}_{2} \quad$ : Kalau segitiganya kongruen jadinya panjang sisi lalu besar sudut sama, sehingga $\mathrm{SP}=\mathrm{QR}$

Berdasarkan penjelasan di atas kedua subjek perempuanmampu memberikan claim dengan tepat. Kedua subjek perempuan juga mampu menunjukkan bukti (evidence) yang dapat mendukung terhadap claim yang diberikan. Namun hanya satu subjek $\mathrm{SP}_{2 y}$ angmampu menyediakan alasan atau penjelasan (warrant) yang tepat berdasarkan postulat kongruensi segitiga. Oleh karena itu $\mathrm{SP}_{1}$ berada pada level 2 dengan indikator yang terpenuhi adalah claim dan evidence dan $\mathrm{SP}_{2}$ berada pada level 3 dengan indikator yang terpenuhi adalah claim, evidence, dan warrant.

Berdasarkan hasil analisis data di atas, tampak bahwa terdapat perbedaan kemampuan argumentasi antara peserta didik laki-laki dan perempuan dalam memecahkan masalah kongruensi segitiga. Hal ini sesuai dengan pendapat Pasiak (2002) yang menunjukkan bahwa terdapat perbedaan cara berpikir antara laki-laki dan perempuan. Peserta didik perempuan memiliki kemampuan argumentasi yang cenderung lebih baik dibandingkan dengan laki-laki. Hal ini tampak dari peserta didik laki-laki hanya mencapai level 1 sedangkan peserta didik perempuan mencapai level 3. Semua peserta didik laki-laki tidak dapat memberikan bukti pendukung yang tepat dari claim yang diajukan karena kurangnya pemahaman mengenai konsep kongruensi segitiga. Pada saat melakukan pembuktian penyataan terkait kongruensi segitiga tentunya diperlukan pemahaman yang baik tentang konsep, postulat dan teorema yang berlaku di dalamnya seperti postulat S-Sd-S, teorema Sd-S-Sd atau teorema S-S-S. Pemahaman yang kurang akan menghasilkan bukti yang tidak 
tepat. Hal ini sesuai dengan pendapat Syamsuri \& Santosa (2017) yang menyatakan bahwa pemahaman matematis peserta didik sangat diperlukan untuk mengkonstruk bukti matematis yang baik.

Lemahnya pemahaman peserta didik terhadap konsep kongruensi mengakibatkan lemahnya subjek dalam mengolah data. Peserta didik terbiasa dalam menggunakan rumus, sehingga dalam menganalisis permasalahan matematika subjek kurang mampu mengaitkan dengan teorema-teorema yang ada. Hal ini sesuai dengan yang dikatakan Firdaus \& Afriansyah (2016) bahwa peserta didik dalam proses belajar mengajar hanya mendengar dan menyimak apa yang diajarkan guru tanpa mengetahui bagaimana cara menemukan dan menarik kesimpulan dari suatu informasi. Dalam kasus ini, mengakibatkan peserta didik kurang kreatif dalam memberikan jawaban.

Selain pemahaman terhadap konsep yang baik, kemampuan koneksi dan penalaran juga sangat dibutuhkan dalam mengkonstruk bukti dan argumen yang benar. Masalah pembuktian yang diberikan pada penelitian ini, membutuhkan kemampuan koneksi dan penalaran pada konsep lingkaran, hubungan dua sudut, jenis dan sifat segitiga serta kongruensi segitiga. Semua peserta didik mampu menemukan informasi yang terkait hubungan antara panjang jari-jari lingkaran dan sudut bertolak belakang pada masalah yang diberikan. Namun hanya peserta didik perempuan yang dapat menghubungkan semua informasi tersebut dengan jenis dan sifat segitiga sama kaki. Sedangkan yang dapat menghubungkan semua informasi dengan konsep kongruensi segitiga hanya satu orang peserta didik perempuan. Hal ini sesuai dengan pendapat Aini \& Hasanah (2019), Salmina \& Nisa (2018) dan Susilowati (2016) yang menyatakan bahwa mengemukakan bahwa kemampuan penalaran dan koneksi peserta didik laki-laki mayoritas lebih rendah dibandingkan dengan kemampuan penalaran matematispeserta didikperempuan. Hal ini disebabkan karena peserta didik laki-laki cenderung kurang cermat dan teliti dalam menyelesaikan soal.

Analisis data di atas juga menunjukkan bahwa level kemampuan argumentasi maksimal yang mampu dicapai oleh peserta didik adalah level 3. Semua peserta didik mampu membuat klaim dengan tepat namun hanya 2 peserta didik yang mampu memberi bukti dukung yang sesuai, 1 peserta didik yang mampu memberi alasan (warrant) yang tepat dan tidak ada peserta didik yang mampu memberikan backing, qualifier dan rebuttal. Hal ini menunjukkan bahwa peserta didik mengalami kesulitan dalam menyusun argumen yang lengkap dan benar dalam menyelesaikan masalah pembuktian kongruensi segitiga. Hasil ini 
memperkuat hasil penelitian yang dilakukan oleh Faruq (2014) dan Pritasari dkk (2016).

Berdasarkan pembahasan di atas, kemampuan peserta didik dalam memahami dan menghubungkan konsep satu dengan yang lain menjadi faktor penyebab utama keberhasilan dalam menyusun argumen yang benar. Oleh karena itu proses pembelajaran perlu untuk menekankan pada penguatan kemampuan pemahaman konsep dan koneksi matematis agar kemampuan argumentasi peserta didikdalam menyelesaikan masalah pembuktian turut meningkat.

\section{SIMPULAN DAN SARAN}

Berdasarkan analisis data dan pembahasan yang telah diuraikan sebelumnya, maka dapat ditarik simpulan bahwa kemampuan argumentasi peserta didik laki-laki berada pada level 1 yang artinya hanya mampu memberikan klaim dengan benar tanpa bisa memberikan bukti dukung dan alasan yang kuat. Peserta didik laki-laki cenderung tidak teliti dan kesulitan membedakan konsep kongruen dan sebangun. Sedangkan peserta didik perempuan mampu mencapai level 3 dalam menyampaikan argumennya yang berarti memiliki kemampuan dalam menyusun claim, evedince, dan warrant yang tepat. Peserta didik perempuan memiliki kemampuan simbolik yang bagus dalam menyusun bukti serta memiliki pemahaman konsep kongruensi yang lebih baik dibanding peserta didik laki-laki.

Kemampuan menyusun bukti pada materi geometricenderung kurang berkembang secara signifikan. Olehkarena itu, peneliti selanjutnya dapatmempertimbangkan modelmodel pembelajaran yang sesuai untuk melatih kemampuan peserta didik dalam mengungkapkanargumentasi terutama dalam proses menyusun bukti. Selain itu modelmodel pembelajaran yang bertujuan meningkatkan pemahaman dan koneksi matematis juga sangat diperlukan untuk mendukung peningkatan kemampuan argumentasi peserta didik dalam memecahkan masalah pembuktian.

\section{DAFTAR RUJUKAN}

Aini, S. D., \& Hasanah, S. I. (2019). Berpikir visual dan memecahkan masalah: Apakah berbeda berdasarkan gender?. JNPM:Jurnal Nasional Pendidikan Matematika, 3(2), 177-190. doi: 10.33603/jnpm.v3i2.2192.

Budiati, A. C. (2010). Aktualisasi diri perempuan dalam sistem budaya Jawa (persepsi perempuan terhadap nilai-nilai budaya Jawa dalam mengaktualisasikan diri). Pamator Journal, 3(1), 51-59. doi: 10.21107/pamator.v3i1.2401.

Faruq, A. (2014). Analisis struktur argumentasi dan kemampuan mengkonstruk bukti matematika siswa sekolah menengah. Skripsi tidak dipublikasikan.Surabaya: UIN Sunan Ampel. 
Firdaus, D. A., \& Afriansyah, E. A. (2016). Pembelajaran kooperatif tipe Team Assisted Individually untuk meningkatkan kemampuan pemahaman matematis siswa sekolah menengah pertama. Jurnal Pendidikan Matematika RAFA, 2(1), 104-122.

Handayani, P. (2015). Analisis argumentasi peserta didik kelas X SMA Muhammadiyah 1 Palembang dengan menggunakan model argumentasi Toulmin". Jurnal Inovasi dan Pembelajaran Fisika, 2(1), 61-68.doi: 10.36706/jipf.v2i1.2355.

Herlanti, Y. (2014). Pemanfaatan media sosial pada pembelajaran sains berbasis isu sosiosaintifik untuk mengembangkan keterampilan berargumentasi dan literasi sains. Bandung: Sekolah Pascasarjana Pendidikan Indonesia.

Meylani, C. F. (2018). Pola dan jenis argumen pada bagian pembahasan artikel jurnal terakreditasi bidang ekonomi. Skripsi tidak dipublikasikan. Yogyakarta: Universitas Sanata Dharma.

Mutohar, A. (2016). Analisis kemampuan pemahaman konsep matematis Kelas IX SMP Negeri 1 Pandanarum pada materi kesebangunan dan kekongruenan. Skripsi tidak dipublikasikan. Purwokerto: Universitas Muhammadiyah Purwokerto.

Nafi'an, M. (2011). Kemampuan siswa dalam menyelesaikan soal cerita ditinjau dari gender di sekolah dasar.Prosiding Seminar Nasional Matematika dan Pendidikan Matematika, 3 Desember 2011.Yogyakarta: Universitas Negeri Yogyakarta,571-577.

Nisa', K. (2017). Profil kemampuan argumentasi siswa dalam menyelesaikan masalab matematika ditinjau dari aktualisasi diri siswa. Skripsi tidak dipublikasikan. Surabaya: UIN Sunan Ampel.

OECD. (2019). PIS A 2018: Insights and Iinterpretations. Paris: OECD.

Pasiak, T. (2002). Revolusi IQ/EQ/SQ. Bandung: Mizan.

Pritasari, A.C., Dwiastuti, S., Probosari, R.M. (2016). Peningkatan Kemampuan Argumentasi melalui Penerapan Model Problem Based Learning pada Siswa Kelas X MIA I SMA Batik Surakarta Tahun Pelajaran 2014/2015. Jurnal Pendidikan Biologi, $8(1), 2$.

Retnosari, F. D. (2017). Analisis kemampuan mahasiswa Program Studi Pendidikan Matematika Universitas Sanata Dharma mengenai kesebangunan dan kekongruenan. Skripsi tidak dipublikasikan. Yogyakarta: FKIP-Universitas Sanata Dharma.

Ruggiero, V. R. (2009). Becoming a critical thinker. Bostom: Hougthon Mifflin Company.

Sadieda, L. U. (2019). Kemampuan argumentasi mahasiswa melalui Model Berpikir Induktif dengan Metode Probing-Prompting Learning. PYTHAGHORAS:Jurnal Pendidikan Matematika, 14(1), 23-32. doi: 10.21831/pg.v14i1.24038

Salmina, M., \&Nisa, S. K. (2018). Kemampuan penalaran matematis berdasarkan gender pada materi geometri. Numeracy Journal, 5(1), 41-48.

Sandoval, W. A., \& Millwood, K. A. (2005). The Quality of student use evidence in written scientific explanations. Cognition and instruction, 23(1), 23-25.

Sunardi, S. \& Yudianto, E. (2015). Antisipasi siswa level analisis dalam menyelesaikan masalah geometri. AdMathEdu, 5(2), 203-216. doi: 10.12928/admathedu.v5i2.4776.

Susilowati, J. P. S. (2016). Profil penalaran siswa SMP dalam pemecahan masalah matematika ditinjau dari perbedaan gender. JRPM: Jurnal Review Pembelajaran Matematika, 1(2), 132-148. doi: 10.15642/jrpm.2016.1.2.132-148. 
Syamsuri \& Santosa, C.AHF. (2017). Karakteristik Pemahaman Mahasiswa Dalam Mengonstruksi Bukti Matematis. JRPM: Jurnal Review Pembelajaran Matematika, 2(2), 131-143. doi:10.15642/jrpm.2017.2.2.131-143

Umroh, H. (2018). Perempuan dan Aktualisasi. Takammul: Jurnal Studi Gender dan Islam Serta Perlindungan Anak, 7(1),46-53. doi: 10.22373/takammul.v1i2.2461.

Walidah, N. Z., Kusaeri, K., Yudi, U. (2019). Mengoptimalkan dukungan guru dalam melibatkan siswa menggunakan argumentasi kolektif pada pembelajaran matematika. MaPan: Jurnal Matematika dan Pembelajaran, 7(2), 261-280. doi: 10.24252/mapan.2019v7n2a7. 